\title{
INCIDENCIA DE LA RESPIRACIÓN ORAL EN PERSONAS CON OCLUSIÓN CLASE II
}

AUTORES: INSTITUCIÓN: PAIS:
Rojas S.M, Parra R.D

Equipo De Investigación De La Motricidad Orofacial Latinoamericana Lima-Perú

\section{RESUMEN:}

Objetivo: Relacionar un determinado tipo de oclusión (Clase II) al modo respiratorio del individuo. Métodos: Se reunió un grupo de personas que, mediante el análisis cefalométrico por parte del ortodoncista, fuesen portadoras de una oclusión Clase II que están en proceso de tratamiento ortodóncico. Se solicitó que, según la ficha ortodóncica, se especifiquen el tipo facial del paciente, si la Clase II era de origen dentaria y/o esquelética, y si había alguna alteración en la mordida (abierta, profunda, ovejet, cruzada unilateral o bilateral), y en el paladar (ojival, atrésico). Luego, cada paciente respondió un cuestionario cerrado con 10 preguntas sobre los síntomas del respirador oral, entre ellas la autopercepción del modo de respiración oral o nasal. Fueron evaluados 36 personas con edades comprendidas entre 8 y 16 años de edad. Resultados: Se observó que un gran número de personas con oclusión Clase II son respiradores orales (75\%), de los cuales la mayoría poseen un tipo facial medio (44\%), seguidos del tipo facial largo (33\%) y por último los de tipo facial corto (22\%). Dentro de los 27 respiradores orales, 12 presentan Clase II dentario; otros 12 , Clase II esquelética y solo 3 , Clase II mixta. Con relación a la tipología facial, se observa que dentro de las personas de tipo facial corto, 3 son portadores de Classe II esqueletal y 6 de Classe II dental y, 6 de esos 9 indivíduos (67\%) son respiradores orales. Dentro de las personas de tipo facial larga, 6 poseen alteración esqueletal y 6 poseen alteración dentaria, y 9 de los 12 individuos (75\%) son respiradores orales. Y, dentro de las personas de tipo facial medio, 3 son portadores de Classe II esqueletal, 9 son portadores de Classe II dentaria y 3 posee alteración mixta, y 12 de esos 15 indivíduos (80\%) son respiradores orales, y también 12 de ellos (80\%) poseen mordida profunda. Se observó también que 15 de los 27 respiradores orales (55.5\%) poseen mordida profunda (6 son tipo facial largo, 12 media y 6 corta), apenas 6 (22\%) mordida cruzada unilateral y 3 (11\%) mordida abierta. Con relación al paladar $55 \%$ de los respiradores orales presentan alteraciones morfológicas (22\% paladar ojival y $33 \%$ paladar atrésico). Se obtuvo también que, dentro de los 12 respiradores nasales, 6 presentan paladar ojival (67\%). Mientras que, el 100\% de los individuos con tipo facial largo tienen alteración morfológica del paladar. Conclusión: Se concluye que existe una mayor incidencia de respiradores orales con tipo facial media de los tipo facial largo. Además se nota la equivalencia de la distribución entre Clase II dentaria (55,5\%, siendo 6 del tipo facial largo y 6 del tipo facial media) y Classe II esquelética (también 55,5\%, siendo 6 del tipo facial largo y 6 del tipo facial media). Sorprende el alto índice de personas con mordida profunda (67\% del total, siendo $55,5 \%$ dentro de los respiradores orales y $100 \%$ dentro de los respiradores nasales).

Palabras clave: Respiración Oral, Incidencia, Oclusión Clase II

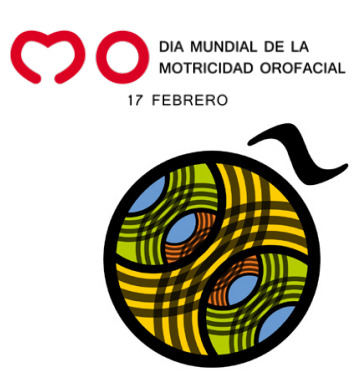

